cent in northern England and Scottish specimens, while Hebridean Island specimens show the complexity in c. 80 per cent of the cases ${ }^{4}$. Out of all the skulls examined (nine) in the present series, only one (11.1 per cent) showed the dental complexity of $M^{3}$.

Comparisons of cranial characters were made with series of British mainland and continental specimens, by Dr. G. B. Corbet in the British Museum (Natural History). The characters compared were hind foot, condylo-basal length, zygomatic width, cranial width, interorbital width, anterior palatal foramina, length of maxillary tooth-row, relative lengths of $M^{1}, M^{2}$ and $M^{3}$, fourth inner loop of $M^{3}$, length of nasals and width across condyles. The only detectable difference is that the nasals are on average shorter and the condyle width greater than British forms, but even here there is considerable overlap.

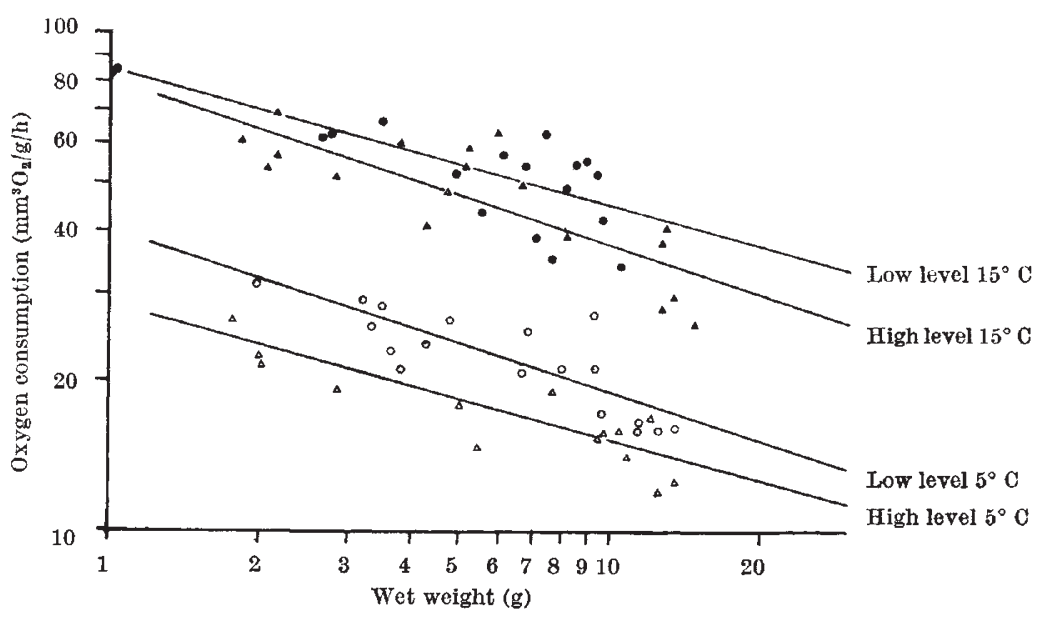

Fig. 1. Respiration rate of high-shore level $(\Delta, \mathbf{\Delta})$ and low-level $(0,0)$ Patella vulgata at $5^{\circ} \mathrm{C}$ and $15^{\circ} \mathrm{C}$ in July 1962. Regression lines are fitted by the method of least squares

From the evidence at present available it would appear that this Irish population is essentially similar to that in England. Trapping in neighbouring counties suggests that this population is restricted in distribution. Investigations now being carried out are aimed at establishing the present distribution of this species in Ireland.

We thank Dr. G. B. Corbet for making comparisons between the specimens and those in the British Museum (Natural History).

Note added in proof. Further specimens have recently been obtained from Co. Limerick, 50 miles from Listowel. A. J. M. ClaAsSens Fergus O'Gorman

Department of Zoology, University College, Cork.

${ }^{3}$ Barrett Hamilton, G. E. H., and Hinton, M. A. G., A History of British Mammals (1910-21).

${ }^{2}$ Millar, G. S., Catalogue of European Mammals in the British Museum (Brit. Mus. (Nat. Hist.), London, 1912).

Moffat, C. B., Proc. Roy. Irish Acad., 44, B (6), 61 (1938). - In Handbook of British Mammals, edit. by Southern, H. N. (Blackwell,

\section{Environmental Acclimation in the Limpet Patella vulgata L.}

THE differences in intertidal distribution of the two British species of prosobranch limpets Patella valgata L. and $P$. aspera Lamarck have been well documented. $P$. aspera is limited to low shore-lovels on shores exposed to wave action, while $P$. vulgata is widely distributed between high and low water levels on both exposed and sheltered shores ${ }^{1,2}$. During my investigation into the reasons for the differences in their distribution in the Clyde Sea area it was found that populations of $P$. vulgata from high shore-levels display physiological differences in several ecologically important characters when compared with those living at low shore-levels. Differences were observed in metabolic rate, the rate of loss of water under desiccating conditions and the ability to withstand loss of body water.

Metabolic rate, determined as the rate of respiration of whole animals in air, was used as an indicator of "internal physiological state" of the animals. Respiration was measured by means of a new type of constant pressure respirometer ${ }^{3}$ and expressed as cubic $\mathrm{mm}$ of oxygen consumed/g wet weight soft parts/h. It was found that in summer the rate of respiration of high-level limpets is significantly lower than that of low-level limpets at temperatures of both $5^{\circ} \mathrm{C}$ and $15^{\circ} \mathrm{C}$ (Fig. 1). These differences in rate of respiration are not found during the winter months but reappear during the spring as the respiration rate of the low-level limpets begins to increase again. The respiration rate of the high-water limpets remains almost constant throughout the year.
For certain Californian molluscs, thermal acclimation has been postulated to explain differences in the rate of pumping of the gills in Mytilus californianus ${ }^{4}$ and rate of heart beat of Acmaea limatula ${ }^{5}$, correlated with differences in tide level. In Patella, present results suggest that intake of food is also a causative factor, since in another series of experiments it was found that of all limpet populations on the seashore, the highest respiratory rate was recorded from those living beneath a cover of fucoid seaweeds and the lowest from a population living on rocks covered with barnacles. Reciprocal transplantation experiments demonstrated that these differences did not result from genetic selection, since after two months high-level limpets transplanted to low-level habitats had a higher respiratory rate than low-level animals which had been transplanted to high levels.

Under desiccating conditions similar to those experienced by the animals on the seashore when uncovered by the tide, it was found that the rate at which water is lost is related to tho size of the limpets. In low-level limpets loss of water is proportional to the power -0.41 of the body-weight, and in limpets from high water-levels, to the power -0.55 of the weight. When compared at the same weight, low-level limpets lose water at a higher rate than high-level ones. In addition, there are differences in tolerance of loss of water during desiccation. In a sample of low-level limpets, 50 per cent succumbed to a loss of water of 50 per cent of their body weight while 50 per cent of a sample of high-level limpets were able to withstand a loss of water of $60-65$ per cent of their body-weight.

It is clearly advantageous to limpets living under the adverse environmental conditions prevailing at high levels on the shore to maintain a lower metabolic rate, withstand greater losses of water and to lose water more slowly than those living at low shore-levels. Evidence is accumulating that ability to acclimate to wide ranges within the environment is of prime importance in the wide intertidal distribution of $P$. vulgata. From other studies, not detailed in this communication, it appears that this ability is not well developed in $P$. aspera.

This work was carried out during the tenure of a Department of Scientific and Industrial Rosearch research studentship, and I thank Dr. C. H. Mortimer and Prof. C. M. Yonge for the provision of research facilities.

\section{P. Spencer Dafies}

Department of Zoology, University of Glasgow, and the Marine Station, Millport.

1 Evans, R. G., Proc. Zool. Soc. Lond., 117, 411 (1947).

Ballantine, W. J., Field Studies, 1, 1 (1961).

${ }^{3}$ Davies, P. Spencer (in the press).

4 Segal, E., Rao, K. P., and James, T. W., Nature, 172, 1108 (1953).

${ }^{5}$ Segal, E., Biol. Bull.,111, 129 (1056). 